\title{
Paradigm Lost: A Reasoned Review of the Literature on the Relationship between Ethics and Technological Innovation
}

\author{
Andrea Carignani \\ Dipartimento di Business, Law, \\ Economics and Consumer Behavior "Carlo A. Ricciardi" \\ Università IULM, via Carlo Bo 1, 20143 Milano \\ Vanessa Gemmo \\ Dipartimento di Business, Law, \\ Economics and Consumer Behavior "Carlo A. Ricciardi" \\ Università IULM, via Carlo Bo 1, 20143 Milano \\ Jacopo Selmi \\ Dipartimento di Business, Law, \\ Economics and Consumer Behavior "Carlo A. Ricciardi" \\ Università IULM, via Carlo Bo 1, 20143 Milano
}

\begin{abstract}
In a society incontrovertibly shaped by information and communication technologies, individuals seem to find it increasingly difficult to acquire sufficient awareness of the consequences of their actions, and subsequently, develop a deep sense of ethical, social, and professional responsibility. Focusing on this fundamental aspect of the complex relationship between ethics and technological innovation, which James Moor defined as a "conceptual muddle", this paper proposes a reasoned, although by no means exhaustive, review of 50 studies that explicitly cite Moor's work and contribute, albeit with different objectives and methods, to a more in-depth examination of the relationship between ethical evaluations and emerging technologies. The papers considered in this review are distinguished by methodological approach and some particularly relevant and recurrent topics, namely policy vacuum, professional responsibility, ethical education, technological revolution, and privacy.
\end{abstract}

Keywords: ethics, information and communication technologies, conceptual muddle.

\section{INTRODUCTION}

For decades now, the increasingly widespread and pervasive diffusion of information technologies has forced professionals, scholars, and more generally ordinary people, to redefine their active position within society (and the labor market) whose connective tissues appear to be increasingly, extensively, and incontrovertibly innervated by these technologies. This constant and inevitable rethinking and critical analysis process, as well as affecting the roles and identities of individuals, is particularly evident in the field of ethical evaluations [42].

In a socio-political-economic context shaped by IT, it is extremely difficult, if not almost impossible, for people to acquire full awareness of the spatial and temporal consequences of their actions, and subsequently, develop a deep sense of ethical and social responsibility. In light of these considerations, it would seem vital that these "new" ethics, born in and from the context created by IT, are firmly based on a principle of responsibility, endowed with a collective, public, and professional dimension and scope [26]. To achieve all this, and translate 
it into a policy commitment at all the different levels of society in which we live, requires first identifying an interpretation key that from a theoretical perspective informs the use and diffusion of IT, and in so doing, identifies the areas of greatest ethical criticality of the so-called Infosphere. In this regard, worth noting is that the importance of information technologies in our society and our economy is on the one hand directly proportional to the degree of complexity of the phenomena and processes that we are called upon to know, understand, and deal with on a daily basis, and on the other hand, inversely proportional to the level of trust that interconnects those involved in these same phenomena and processes.

The conceptual framework emerging here, enriched by the contributions of many authors who since the mid-80s have dealt with these issues and propose interesting interpretative models, allows recognizing the domains and ways of using IT, inevitably calling for urgent ethical reflection. In this sense, taking a first look at these models, we take cue from the now classic framework that Richard Mason proposed in 1986 in a paper titled Four Ethical Issues of the Information Age. After defining information as "the means through which the mind expands and increases its capacity to achieve its goals" [28, p. 5], the author identifies four main areas in which the use of IT renders "the intellectual capital from which human beings craft their lives and secure dignity" [ibid] vulnerable and extremely problematic from an ethical point of view: privacy, accuracy, property, and accessibility (PAPA). Among these four areas of high ethical criticality, the first concerns the complex demarcation between disclosable and confidential information; the second is centered on the responsibility for the accuracy, reliability, and authenticity of the information itself; the third refers to the possession of information and the channels through which it is transmitted; and the fourth is inherent in the type of information that an individual or a collective has the right to obtain [ibid].

To note is that although variously reworked and extended over the years in relation to the extraordinary leaps made by new and emerging information and communication technologies [47], Mason's work still remains a constant point of reference for the entire disciplinary field of so-called computer ethics [30,39].

Also interesting to take into account are the contributions of some scholars who in parallel to identifying the areas of greatest ethical concern of the Infosphere have highlighted that the new context originating from the rapid and profound transformation of IT, formatively representing the principle according to which "we are living in a period of technology that promises dramatic changes and in which it is not satisfactory to do ethics as usual" [35, p. 111], decisively contributes to making the contours of the ethical issues raised by the spread and importance of IT itself increasingly flexible, nuanced and, in some cases, even controversial. Indeed, research conducted by scholars, such as, for example, Almasri and Tahat [1], with particular reference to data collected from university students, highlights that within a sociocultural environment dominated by the technologies in question, the threshold of tolerance towards their more ethically problematic methods of use is significantly raised $[1,3,33,38]$. Therefore, and as previously recalled, "information technology can create the illusion that a specific action or behavior is all right because it distances the individual from consequences of that action or behavior" [33, p. 667]. People, by now completely immersed in the so-called digital context, ultimately seem to encounter increasing difficulties in defining their own ethical paradigm of reference, more or less struggling in a real "conceptual muddle" [35, p. 115]. Thus, focusing on James Moor's reflections on this theme in his aforementioned 2005 paper titled Why we need a Better Ethics for Emerging Technologies, this paper proposes a reasoned review, although by no means exhaustive, of 50 studies that explicitly and substantially cite the aforementioned work of Moor, and with often heterogeneous objectives and methods 
contribute to a deeper analysis of the complex relationship between ethical evaluations and technological innovations.

\section{DISCUSSION}

In light of these considerations and the data gathered in (Annex A) Table 1, to first note is that the relationship between ethics and IT, in view of the latter's ever-increasing and often irreversible pervasiveness, appears increasingly complex and tangled. In fact, "as technological revolutions increase their social impact, ethical problems increase" [35, p. 117], the levels in which this same relationship is articulated are inextricably intertwined and superimposed, to the point of suggesting the convergence of different interpretative variables and the integration of several methodological and research approaches: from the theoreticalphilosophical to the socio-cultural, from the technical-technological to the legal. Moreover, none of these analyses are sufficient in themselves to dissipate the depth and difficulty of the ethical questions raised by the widespread diffusion and dizzying pace of technological innovations.

The composition of Table 1 thus reflects (even if only partially) on the one hand the extent of the ethical problems that afflict the Infosphere, and on the other, the interdisciplinary way in which these problems are addressed by scholars with different training, sensitivity, and intent. In this regard, the 50 studies in Table 1 can be first subdivided according to a methodological criterion, separating the strictly theoretical contributions [e.g., 4, 18, 53, 56, 62] from those of an empirical nature, in turn subdivided into qualitative [e.g., 43, 63], and quantitative [e.g., 32, $50,60]$.

According to this first subdivision, there is a clear majority of so-called conceptual papers compared to both types of empirical studies.

Secondly, these studies can be distinguished and grouped based on some particularly relevant and recurrent topics (graphically represented in Figure 1), amongst which, for instance, the policy vacuum theme stands out. With this categorization, many of those who study the relationship between ethics and technological innovation identify the planning and strategic insufficiency with which ethical criticalities are addressed, which IT, as previously mentioned, necessarily brings with it. In other words, a lack of governance that today's society is committed to fill from a political, regulatory, and professional point of view to face the ethical challenges presented by the convergence and omnipervasiveness of information technologies with a sufficient level of understanding and planning. Among the studies in Table 1 that focus on this delicate and crucial issue, referring to different technological contexts (such as, for instance, mass communications, drones, nanotechnology, and brain imaging), using various analysis methods, we recall: Brownsword [6], Hester et al. [15], Ienca [21], Leese [25], Nelson and Gorichanaz [36], Stahl et al. [48], Wogu et al. [61].

In light of the contributions listed above, it may be useful to dwell for a moment on the challenge that these policy vacuums pose to a society like ours that is increasingly shaped by new technologies. As is immediately clear, "the challenge is to conceptualize a future careoriented approach which is responsive to uncertainty and sufficiently flexible to be able to keep pace with and adapt to evolving scientific knowledge" [15, p. 128]. To fill the dangerous policy vacuums that accompany the unrelenting march of IT would first of all require "the creation of space for theoretically informed dialogue in a real-world context among a different range of stakeholders who have divergent values and desired outcomes" [ibid, p. 134]. Whenever the planning perspective is lost, the creation of a regulatory environment imposes itself; in other words, "regulatory choices [...] must thus seek to render development and design of emerging 
technologies desirable in the sense that the ensuing outcomes contribute to desirable societal conditions" [25, p. 1600].

Giving life to these sets of norms that can be interpreted not only legally, but also (if not above all) in a socio-political-cultural sense, entails enormous theoretical and practical difficulties in the face of which a rigidly prescriptive approach appears to be largely inadequate. In fact, a unilaterally top-down governance model only capable of intervening on the relationship between ethics and technological innovations ex post would seem unable to compensate for the delay accumulated [ibid.]. For this reason, according to many scholars who address this thorny issue, "approaches to governance need to be able to capture both present and future concerns" $[15$, p. 134] in such a way as to solicit the development of an "intellectual and societal capacity to anticipate negative consequences before they arise in the hope that such an approach could be the antithesis of the retrospective imposition of responsibility after the harm has already been done" [ibid].

Prior to proceeding with the commentary on the studies collected in Table 1, the futureoriented attitude briefly introduced here cannot be considered entirely free of criticism. In this sense, Horner [17], for example, states: "I don't believe that 'policy vacuums' [...] might be filled in advance by anticipating them" [ibid, p. 258], and a few pages later: "My argument therefore is that the conditions required for the kind of foresight (knowledge about the future) to warrant the use of forecasting are almost entirely lacking. This is a radically skeptical position. We simply don't have and indeed cannot have the requisite information about the future" [ibid, p. 263].

As is evident from these affirmations, the author of the paper in question decisively attacks the optimism (in his opinion, almost idealistic) of those who face the ethical criticalities of the Infosphere with a markedly proactive attitude. After all, as Horner himself reiterated: "The application of moral concepts and principles to new situations shaped by radical new technologies may be a matter of decision rather than definition; decisions which cannot be made before the event" [ibid, p. 265]. Without going further into this rugged philosophical terrain, this brief reference to one of the theoretical discussions arising from the policy vacuum problem, far from resolving its complexity, is deemed sufficient to determine, even if only vaguely, the vastness of the problem.

Having said that, another important concept that many studies in this review recall, even if with different objectives and argumentations, is that of responsibility, first of all in relation to various professional fields, whereby "focusing solely on technical details, there is a danger of "tunnel vision" in design of technology" [31]. Therefore, the term responsibility in this sense implies awareness of the impact, risk, and sustainability, especially in socio-economic terms, of the policy choices that support and determine the behavior of professionals involved in the design and development of new technologies. In this sense, we refer to, for instance, Chatfield et al. [8], Davison et al. [10], Meek et al. [29], Small [46], Wakunuma and Stahl [59].

To focus on this aspect of the relationship between ethical evaluations and IT, it may be useful to stress that for those who dedicate themselves professionally to the research and implementation of new technologies, it is extremely important to address and understand their work through two complementary levels of critical reflection. On the one hand, scientists and engineers are called on to adopt first-level analytical skills, expressed in an "iterative process by which a professional experimentally finds solutions to problems using several lines of inquiry" [44, p. 772]. On the other hand, they should be able to carry out their tasks, clarifying, by virtue of meta-reflexive activities, the various assumptions that motivate their decisions and actions. Therefore, this second-order reflective learning, "involves reflection 'on' the research system, 
including the value-based socio-ethical premises that drive research, the methodological norms of the research culture, and the epistemological and ontological assumptions upon which science is founded: the background theories and values of the research system itself become the object of learning" [ibid]. Ultimately, only through making use of these two levels of reflective learning can so-called IT professionals really demonstrate their ability to consciously, and hence responsibly, define their indispensable role within the technological galaxy and its related society.

As other contributions in Table 1 testify, the boundaries of this very discourse can extend beyond considerations strictly related to IT professionals. In fact, so that every active member of the current (and future) society is in a position to acquire sufficient awareness of the direct and indirect consequences of the constant and almost inevitable interactions with IT, and therefore develop a deep and far-sighted sense of ethical and social responsibility, it is vital to focus on the main sources of training of future generations, not only professionals, but also scholars and policymakers. Here, education in the discussion, study, and ethical evaluation of the most problematic and controversial uses of emerging technologies can play a fundamental role in providing the protagonists of some of the more pressing challenges of our time with a compass that allows them to orient themselves between one policy vacuum and another, and a beacon capable of removing, even temporarily, the mists of the conceptual muddle. In this regard, studies dedicated to the theme of ethical education include, for instance, Hoover et al. [16], Huggard and McGoldrick [20], Lau and Yuen [24], Saab [40], Tolnaiová [55].

To note is that, despite the purely illustrative value of the studies just mentioned, this very small sample of works dedicated to ethical education points to the great importance and effectiveness of multidisciplinarity. In fact, only by drawing on the technical and theoretical knowledge of scholars and professionals from the most diverse disciplines can we attempt to outline, albeit in a relative and always integrative form, a paradigm that allows individuals immersed in the Infosphere to critically understand and actively address the most ethically problematic aspects of the digital context. In other words, to be able to profitably deepen the understanding of the complex relationship between ethics and technological innovation, the construction of a "common ground between scientific and ethical expertise from which the wider ramifications of scientific developments can be assessed at the earliest possible stage" [43, p. 208] is decisive.

Continuing the analysis of the most recurrent topics among the studies in Table 1 requires referring to the concept of technological revolution, the real backbone of Moors' entire reflection. In this regard, starting from the preliminary assumption that "the impact of the technology on society is what marks it essentially as revolutionary" [35, p. 112], the author of the essay on which this entire review is based believes that technological revolutions are characterized by three different development stages: "the introduction stage, the permeation stage, and the power stage" [ibid]. In the passage from one revolutionary stage to the next, the pervasiveness of the technology in question progressively increases, its production becomes more and more massive, its costs decrease, and last but not least, the controversies of an ethical nature that it generates become deeper and more inextricable. As Moor himself rightly pointed out, to be able to unfold in this way, this technological revolution model can only be placed in a "liberal democratic state in which market forces, even if regulated, play an important role" [ibid]. In light of these considerations, among the studies of Table 1 that refer to the theoretical framework briefly outlined, we recall: Horner [19], Mariscal and Petropanagos [27], Stylianou and Talias [51]. 
Before proceeding, it may be of some interest to point out that the aforementioned David Horner directly criticized Moor's theoretical approach, contesting the teleological ineluctability, and denouncing it as technological determinism. According to the author, "revolution has all the qualities of a metaphor out of control" [19, p. 304], since "this way of putting things seems to suggest that technologies are some form of force external to society that will [...] radically transform our life world" [ibid, p. 302]. In sum, although the discussion of such criticism would end up transcending the scope and objectives of this paper, according to Horner himself, the concept of technological revolution developed by James Moor and briefly set out here "overstates characteristics of (technical) novelty, upheaval and inevitability at the expense of a more subtle appreciation of the role of social, economic, cultural and ethical values in shaping the trajectories of information and communication technologies" [ibid, p. 307].

Among the most transversal topics of the entire review, the by-now classic issue of privacy merits a mention, as referred to in the introductory paragraph, and to which we now return, highlighting from among many others the following studies: Bülow and Wester [7], Culnan and Williams [9], De Saulles and Horner [11], Friedewald et al. [13], Jurkiewicz [23], Tavani and Grodzinsky [52], Turculeţ [57].

As can be seen from the variety of these partial references, privacy is one of the most burning and mandatory ethical issues among those raised within the magmatic IT landscape. Given the impossibility of venturing into even a superficial analysis of the countless philosophical ${ }^{1}$ or socio-cultural facets (just to mention a few) of this fundamental theoretical juncture, it may be useful to highlight that, precisely due to its enormous complexity, this theme, which for decades has engaged anyone looking critically at the universe of information and communication technologies, constitutes a unique field of convergence for all the topics (policy vacuum, professional responsibility, ethical education, technological revolution) dealt with in this paper. Thus, in the final analysis, the literature review presented in Table 1, reaffirming that the central issue of privacy imposes itself on the attention of commentators in every possible interpretation of the relationship between ethics and technological innovation, follows, at least to some extent, in the path of the aforementioned PAPA framework that Mason proposed in 1986, and subsequently deepened and consolidated by Ming et al. [30] and Peslak [39], amongst others.

1 For a significant theoretical-philosophical study on this subject, see Moor [34] and Nissenbaum [37]. 
Figure 1. Studies grouped according to methodology and relevant topics (our elaboration).

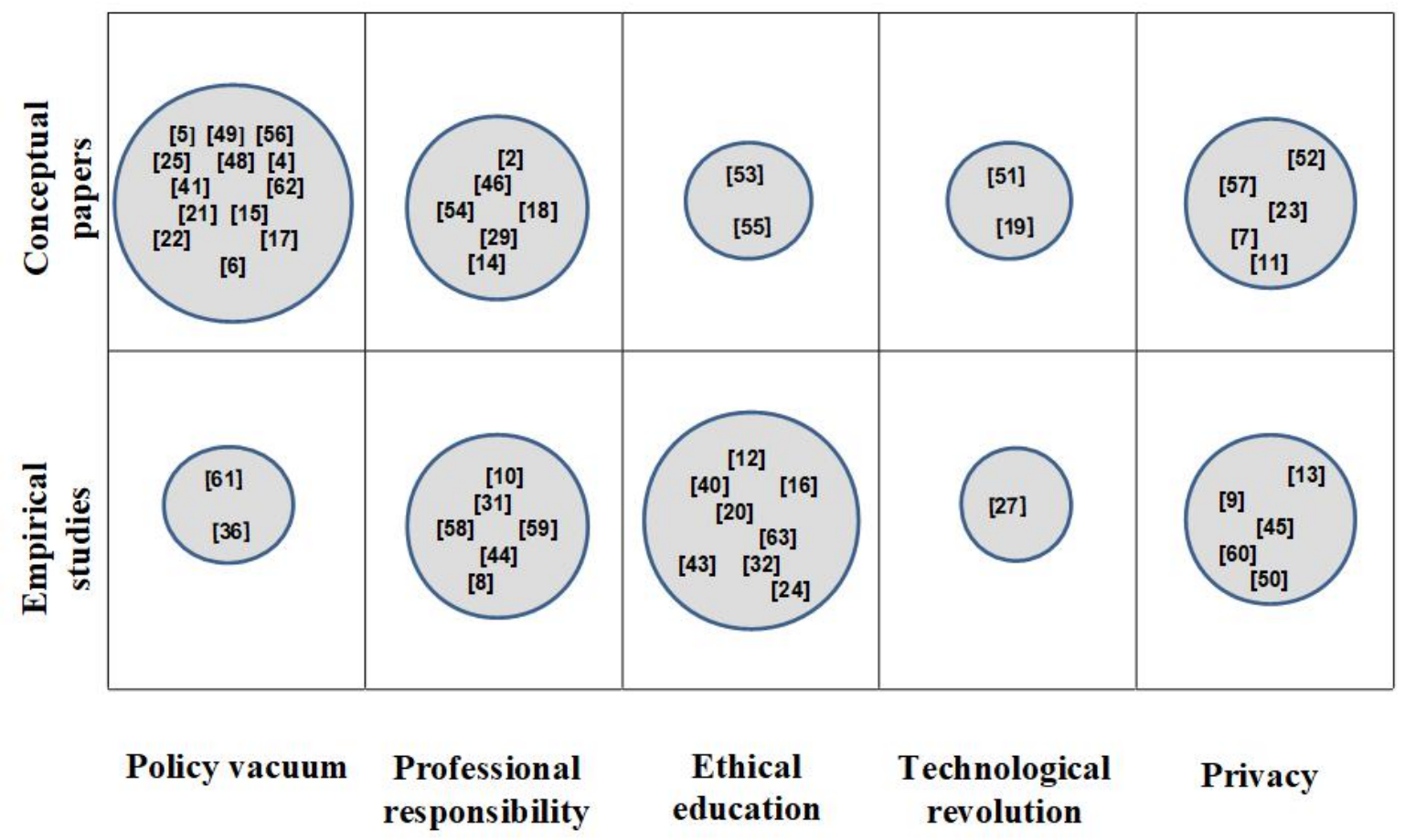

\section{CONCLUSION}

This reasoned literature review, starting from some general reflections on the complex relationship between ethical evaluations and technological innovations, highlights, albeit not exhaustively, that individuals struggling with ever-pervasive technologies are finding it increasingly difficult to define their own ethical paradigm of reference. The conceptual muddle, enveloping the entire digital context, affects the relationship between ethics and emerging technologies in every possible way, including those on which we focus here with the help of the studies collected in Table 1. In this regard, the topics identified as the most relevant are: policy vacuum, professional responsibility, ethical education, technological revolution, and privacy. The largely partial, relative, and conceptual nature of the present research on the one hand necessarily lends itself to numerous revisions and integrations of a theoretical nature, and on the other hand, might to some extent offer potentially interesting cues for empirical and quantitative investigations. In particular, this research provided the theoretical framework of reference for the creation of a questionnaire, within the ISEA (Information Systems Ethical Attitudes) research project, promoted by the Department of Business, Law, Economics and Consumer Behavior "Carlo A. Ricciardi" of IULM University of Milan, the Appalachian State University and the University of Évora to 1868 university students in 8 different countries (USA, Spain, Portugal, Italy, Czech Republic, Hungary, Kazakhstan and Cape Verde) with the aim of recording the various attitudes and perceptions toward ethical issues in the use of Information Technologies.

\section{References}

Almasri, N., \& Tahat, L. (2018), "Ethics Vs IT Ethics: a Comparative Study between the USA and the Middle East", Journal of Academic Ethics, 16(4), pp.329-358.

Bacchini, F. (2013), “Is nanotechnology giving rise to new ethical problems?”, Nanoethics, 7(2), pp.107-119. 
Banerjee, D., Cronan, T. P., \& Jones, T. W. (1998), "Modeling IT Ethics: A Study in Situational Ethics “, MIS Quarterly, 22(1), pp.31-60.

Brey, P. A. (2012), "Anticipating ethical issues in emerging IT”, Ethics and Information Technology, 14(4), pp.305317.

Brownsword, R. (2009a), “Nanoethics: old wine, new bottles?”, Journal of consumer policy, 32(4), pp.355-379.

Brownsword, R. (2009b), "Regulating brain imaging: challenge and opportunity", Frontiers in human neuroscience, 3,50 .

Bülow, W., \& Wester, M. (2011), "Privacy issues and Paternalism in the context of Social Networking Sites”, 12th International conference on the Social and Ethical Impacts of Information and Communication Technology (ETHICOMP), pp.88-93.

Chatfield, K., Borsella, E., Mantovani, E., Porcari, A., \& Stahl, B. (2017), “An investigation into risk perception in the ICT industry as a core component of responsible research and innovation”, Sustainability, 9(8), 1424.

Culnan, M. J., \& Williams, C. C. (2009) ,"How ethics can enhance organizational privacy: lessons from the choicepoint and TJX data breaches", Mis Quarterly, 33(4), pp.673-687.

Davison, R. M., Martinsons, M. G., Ou, C. X., Murata, K., Drummond, D., Li, Y., \& Lo, H. W. (2009), "The ethics of IT professionals in Japan and China", Journal of the Association for Information Systems, 10(11), pp.834-859.

De Saulles, M., \& Horner, D. S. (2011), “The portable panopticon: morality and mobile technologies”, Journal of Information, Communication and Ethics in Society, 9(3), pp.206-216.

Duho, K. C. T., Onumah, J. M., Simpson, S. N. Y. \& Onumah, R. M. (2019), “Emerging Technologies, Corporate Social Responsibility and Sustainability: Perception of Business Students in Ghana", Academy of International Business (AIB) Africa Conference 4-7 August 2019, Accra, Ghana.

Friedewald, M., Wright, D., Gutwirth, S., \& Mordini, E. (2010), "Privacy, data protection and emerging sciences and technologies: towards a common framework", Innovation-The european journal of social science research, 23(1), pp.61-67.

Harris, I., Jennings, R. C., Pullinger, D., Rogerson, S., \& Duquenoy, P. (2011), “Ethical assessment of new technologies: a meta-methodology", Journal of Information, Communication and Ethics in Society, 9(1), pp.49-64.

Hester, K., Mullins, M., Murphy, F., \& Tofail, S. A. (2015), “Anticipatory ethics and governance (AEG): Towards a future care orientation around nanotechnology", NanoEthics, 9(2), pp.123-136.

Hoover, E., Brown, P., Averick, M., Kane, A., \& Hurt, R. (2009), “Teaching small and thinking large: Effects of including social and ethical implications in an interdisciplinary nanotechnology course", Journal of Nano Education, 1(1), pp.86-95.

Horner, D. (2007), "Forecasting ethics and the ethics of forecasting: the case of nanotechnology", 8 th International conference on the Social and Ethical Impacts of Information and Communication Technology (ETHICOMP), pp.257267.

Horner, D. S. (2010a), "Moral luck and computer ethics: Gauguin in cyberspace”, Ethics and information technology, 12(4), pp.299-312.

Horner, D. S. (2010b), "Metaphors in orbit: revolution, logical malleability, generativity and the future of the internet", $11^{\text {th }}$ International conference on the Social and Ethical Impacts of Information and Communication Technology (ETHICOMP), pp.301-308.

Huggard, M., \& McGoldrick, C. (2014), "Enhancing Ethical Awareness through Practical Engagement with Mobile Media", International Conference on Engineering Education and Research, McMaster University in Hamilton, Ontario from August 24 to 26, 2014, Ontario, Canada.

Ienca, M. (2018), “Democratizing cognitive technology: a proactive approach”, Ethics and Information Technology, pp.1-14, Web.

Iqbal, J., \& Beigh, B. M. (2017), “Computer Ethics from Obscure to Ubiquitous”, International Journal of Advanced Research in Computer Science, 8(3). pp.983-990.

Jurkiewicz, C. L. (2018), “Big Data, Big Concerns: Ethics in the Digital Age”, Public Integrity, 20(sup1), pp.S46-S59.

Lau, W. W., \& Yuen, A. H. (2013), “Adolescents' risky online behaviours: The influence of gender, religion, and parenting style”, Computers in Human Behavior, 29(6), pp.2690-2696. 
Carignani, A., Gemmo, V., \& Selmi, J. (2019). Paradigm Lost: A Reasoned Review of the Literature on the Relationship between Ethics and Technological Innovation. Advances in Social Sciences Research Journal, 6(12) 168-180.

Leese, M. (2017), "Holding the project accountable: Research governance, ethics, and democracy", Science and engineering ethics, 23(6), pp.1597-1616.

Maggiolini, P. (2013), “Computer Ethics. Un approfondimento”, Mondo Digitale, 45(1), pp.1-15.

Mariscal, C., \& Petropanagos, A. (2016), "CRISPR as a driving force: the Model T of biotechnology”, Monash bioethics review, 34(2), pp.101-116.

Mason, R. O. (1986), "Four Ethical Issues of the Information Age", MIS Quarterly, 10(1), pp.5-12.

Meek, T., Barham, H., Beltaif, N., Kaadoor, A., \& Akhter, T. (2016), "Managing the ethical and risk implications of rapid advances in artificial intelligence: a literature review", 2016 Portland International Conference on Management of Engineering and Technology (PICMET), pp.682-693.

Ming, T. M., Jabar, M. A., Sidi, F., \& Wei, K. T. (2015), "A systematic literature review of computer ethics issue", Journal of Theoretical and Applied Information Technology, 78(3), pp.360-372.

Mladenović, M. N., Abbas, M., \& McPherson, T. (2014), “Development of socially sustainable traffic-control principles for self-driving vehicles: The ethics of anthropocentric design", Proceedings of the IEEE 2014 International Symposium on Ethics in Engineering, Science, and Technology.

Mohamud, I. K., Zeki, A. M., \& Saidin, A. Z. (2016), “The Case of International Islamic University Malaysia”, International Journal of Soft Computing, 11(4), pp.236-241.

Molnar, K. K., Kletke, M. G., \& Chongwatpol, J. (2008), "Ethics vs. IT Ethics: Do Undergraduate Students Perceive a Difference?", Journal of Business Ethics, 83(4), pp.657-671.

Moor, J. H. (1997), "Towards a Theory of Privacy for the Information Age”, Computers and Society, 27(3), pp.27-32.

Moor, J. H. (2005), "Why we need a better ethics for emerging technologies”, Ethics \& Information Technology, 7(3), pp.111-119.

Nelson, J., \& Gorichanaz, T. (2019), “Trust as an ethical value in emerging technology governance: The case of drone regulation", Technology in Society.

Nissenbaum, H. (2004), "Privacy as Contextual Integrity”, Washington Law Review, 79(1), pp.119-157.

Paradice, D. (1990), "Ethical Attitudes of Entry-Level MIS Personnel”, Information \& Management, 18, pp.143-151.

Peslak, A. (2006), "PAPA revisited: A current empirical study of the Mason framework", Journal of Computer Information Systems, 46(3), pp.117-123.

Saab, D. J. (2010), “Teaching information ethics in an iSchool”, International Review of Information Ethics, 14, pp.10-16.

Sandberg, A. (2019), "There is plenty of time at the bottom: the economics, risk and ethics of time compression", Foresight, 21(1), pp.84-99.

Saponaro, M. B. (2017), "L'inattualità dell'etica nel cyberspazio", Mondo Digitale, 71(4), pp.1-5.

Schuurbiers, D., Sleenhoff, S., Jacobs, J. F., \& Osseweijer, P. (2009), "Multidisciplinary engagement with nanoethics through education - the Nanobio-RAISE Advanced Courses as a case study and model", Nanoethics, 3(3), pp.197211.

Schuurbiers, D. (2011), "What happens in the lab: Applying midstream modulation to enhance critical reflection in the laboratory", Science and engineering ethics, 17(4), pp.769-788.

Singh, D. (2019), "Ethical Dilemmas on Data Privacy and Security for Social Media's Users", Proceedings of International Conference on Media Ethics 2019.

Small, B. (2017), "Digital technology and agriculture: Foresight for rural enterprises and rural lives in New Zealand", J. Agr. Environ. Sci, 6(2), pp.54-77.

Stahl, B. C., Timmermans, J., \& Flick C. (2017), "Ethics of Emerging Information and Communication Technologies. On the implementation of responsible research and innovation", Science and Public Policy, 44(3), pp.369-381.

Stahl, B. C., Heersmink, R., Goujon, P., Flick, C., van den Hoven, J., Wakunuma, K., Ikonen, V., \& Rader, M. (2010), "Identifying the ethics of emerging information and communication technologies: An essay on issues, concepts and method", International Journal of Technoethics, 1(4), pp.20-38. 
Stahl, B. C., Rogerson, S. \& Wakunuma, K. (2009), "Understanding Ethical Issues of Emerging AmI Technologies in Europe (A Framework)", Proceedings of the 1st International Workshop on Ethical Design of Ambient Intelligence in conjunction with the 5th International Conference on Intelligent Environments (IE09), 20-21 July 2009, Technical University of Catalonia, Barcelona, Spain.

Stern, S. E., \& Grounds, B. E. (2011), “Cellular Telephones and Social Interactions: Evidence of Interpersonal Surveillance", International Journal of Technoethics, 2(1), pp.43-49.

Stylianou, A., \& Talias, M. A. (2015), “The 'Magic Light': A Discussion on Laser Ethics”, Science and engineering ethics, 21(4), pp.979-998.

Tavani, H. T., \& Grodzinsky, F. S. (2019), "Responding to Some Challenges Posed by the Re-identification of Anonymized Personal Data", Computer Ethics-Philosophical Enquiry (CEPE) Proceedings, 2019(1), 2.

Tavani, H. T. (2017), "Incorporating a Critical Reasoning Component into the ICT-Ethics Methodological Framework", ORBIT Journal, 1(2).

Timmermans, J., Stahl, B. C., Ikonen, V., \& Bozdag, E. (2010), "The ethics of cloud computing: A conceptual review", 2010 IEEE Second International Conference on Cloud Computing Technology and Science, pp.614-620.

Tolnaiová, S. G. (2014), “Determinants of Humanising Effect of Modern (Electronic) Media”, European Journal of Science and Theology, 10, pp.195-206.

Tolnaiová, S. G. (2016), “Contemporary Internet: Its Existential Dimension and Sociocultural Effect”, European Journal of Science and Theology, 12(5), pp.61-72.

Turculeţ, M. (2014), "Ethical issues concerning online social networks", Procedia-Social and Behavioral Sciences, 149, pp.967-972.

Van Rijmenam, M., Schweitzer, J., \& Williams, M. A. (2019), “Overcoming principal-agent problems when dealing with artificial agents: Lessons for governance from a conversation with Tay”, Preprint.

Wakunuma, K. J., \& Stahl, B. C. (2014), “Tomorrow's ethics and today's response: An investigation into the ways information systems professionals perceive and address emerging ethical issues", Information Systems Frontiers, 16(3), pp.383-397.

Winter, J. S. (2014), "Surveillance in ubiquitous network societies: normative conflicts related to the consumer instore supermarket experience in the context of the Internet of Things", Ethics and Information Technology, 16(1), pp.27-41.

Wogu, J. O., Ezenwaji, I. O., Ololo, K. O., Agboti, I. C., \& Nwobi, U. A. (2018), "Ethical and policy issues in current trends of media technological and mass communication development in nigerian society: perspective from ICT administrative management and sociology", International Journal of u-and e-Service, Science and Technology, 11(1), pp.65-74.

Wright, D. (2011), "A framework for the ethical impact assessment of information technology", Ethics and information technology, 13(3), pp.199-226.

Zevenbergen, B., Mittelstadt, B., Véliz, C., Detweiler, C., Cath, C., Savulescu, J., Whittaker, M. (2015), Philosophy meets Internet Engineering: Ethics in Networked Systems Research (GTC Workshop outcomes paper), Oxford Internet Institute, University of Oxford. 
Carignani, A., Gemmo, V., \& Selmi, J. (2019). Paradigm Lost: A Reasoned Review of the Literature on the Relationship between Ethics and Technological Innovation. Advances in Social Sciences Research Journal, 6(12) 168-180.

\section{ANNEX A - TABLE 1. 50 STUDIES THAT CITE MOOR [35] (OUR ELABORATION).}

\begin{tabular}{|c|c|c|c|}
\hline $\mathbf{N}$ & Contribution & Purpose & Methodology \\
\hline [2] & Bacchini 2013 & $\begin{array}{l}\text { This paper focuses on the question of whether nanotechnology is giving rise to } \\
\text { new ethical problems rather than merely to new instances of old ethical } \\
\text { problems. }\end{array}$ & $\mathrm{CP}$ \\
\hline [4] & Brey 2012 & $\begin{array}{l}\text { This paper presents a new approach to the ethics of emerging information } \\
\text { technology called anticipatory technology ethics. }\end{array}$ & $\mathrm{CP}$ \\
\hline [5] & $\begin{array}{l}\text { Brownsword } \\
2009 \text { a }\end{array}$ & $\begin{array}{l}\text { This paper focuses on the question of whether "nanoethics" should be treated } \\
\text { as a special essay in ethics. }\end{array}$ & $\mathrm{CP}$ \\
\hline [6] & $\begin{array}{l}\text { Brownsword } \\
2009 \mathrm{~b}\end{array}$ & $\begin{array}{l}\text { This paper focuses on the challenge of creating the right kind of regulatory } \\
\text { environment for new brain imaging technologies. }\end{array}$ & $\mathrm{CP}$ \\
\hline [7] & $\begin{array}{l}\text { Bülow \& } \\
\text { Wester } 2011\end{array}$ & $\begin{array}{l}\text { This paper discusses several practical solutions of how to protect people } \\
\text { against the risks of social networking sites and shows how they are related to } \\
\text { the issue of paternalism. }\end{array}$ & $\mathrm{CP}$ \\
\hline [8] & $\begin{array}{l}\text { Chatfield et al. } \\
2017\end{array}$ & $\begin{array}{l}\text { This paper examines the extent to which risk management, including ethical } \\
\text { and social issues, is relevant to companies. }\end{array}$ & QN-R \\
\hline [9] & $\begin{array}{l}\text { Culnan \& } \\
\text { Williams } 2009\end{array}$ & $\begin{array}{l}\text { This paper focuses on managerial responsibility for firms' organizational } \\
\text { privacy behaviors. }\end{array}$ & QL-R \\
\hline [10] & $\begin{array}{l}\text { Davison et al. } \\
2009\end{array}$ & $\begin{array}{l}\text { This paper examines the ethical reasoning of IT professionals in Japan and in } \\
\text { the People's Republic of China. }\end{array}$ & QN-R \\
\hline [11] & $\begin{array}{l}\text { De Saulles \& } \\
\text { Horner } 2011\end{array}$ & $\begin{array}{l}\text { The purpose of this paper is to explore ethical issues arising from the mass } \\
\text { deployment of mobile technologies. }\end{array}$ & $\mathrm{CP}$ \\
\hline [12] & $\begin{array}{l}\text { Duho et al. } \\
2019\end{array}$ & $\begin{array}{l}\text { This paper examines how students' embracing, knowledge and ability to make } \\
\text { business cases out of the emerging technologies affect corporate social } \\
\text { responsibility. }\end{array}$ & QN-R \\
\hline [13] & $\begin{array}{l}\text { Friedewald et } \\
\text { al. } 2010\end{array}$ & $\begin{array}{l}\text { This paper aims at reconceptualizing the concept of privacy and developing } \\
\text { means for the assessment of privacy impacts. }\end{array}$ & QL-R \\
\hline [14] & $\begin{array}{l}\text { Harris et al. } \\
2011\end{array}$ & $\begin{array}{l}\text { This paper sets out a structured meta-methodology for the ethical assessment } \\
\text { of new and emerging technologies. }\end{array}$ & $\mathrm{CP}$ \\
\hline [15] & $\begin{array}{l}\text { Hester et al. } \\
2015\end{array}$ & $\begin{array}{l}\text { The purpose of this paper is to foster the building of intellectual capacity to } \\
\text { anticipate negative consequences and to contribute to the long-term } \\
\text { sustainability of nanotechnologies. }\end{array}$ & $\mathrm{CP}$ \\
\hline [16] & $\begin{array}{l}\text { Hoover et al. } \\
2009\end{array}$ & $\begin{array}{l}\text { This paper describes an interdisciplinary nanotechnology university course } \\
\text { and the ways in which the opinions of students regarding the ethical } \\
\text { implications of nanotechnology research were influenced by this course. }\end{array}$ & QN-R \\
\hline [17] & Horner 2007 & $\begin{array}{l}\text { This paper challenges the view that there can be any moral obligation to } \\
\text { foresee the eventual outcomes of social and technological changes. }\end{array}$ & $\mathrm{CP}$ \\
\hline [18] & Horner 2010a & $\begin{array}{l}\text { The paper describes the nature of moral luck and shows how it poses a } \\
\text { challenge to the theoretical approaches often deployed in Computer Ethics. }\end{array}$ & $\mathrm{CP}$ \\
\hline [19] & Horner 2010b & $\begin{array}{l}\text { This paper argues that the concept of "technological revolution" is useless in } \\
\text { understanding the emergence of information technologies and in constructing a } \\
\text { better IT ethics. }\end{array}$ & $\mathrm{CP}$ \\
\hline [20] & $\begin{array}{l}\text { Huggard \& } \\
\text { McGoldrick } \\
2014\end{array}$ & $\begin{array}{l}\text { This paper explores undergraduate students' ethical awareness of the use of a } \\
\text { range of mobile technologies. }\end{array}$ & QN-R \\
\hline [21] & Ienca 2018 & $\begin{array}{l}\text { This paper decsribes an approach to the democratization of cognitive } \\
\text { technologies. }\end{array}$ & $\mathrm{CP}$ \\
\hline [22] & $\begin{array}{l}\text { Iqbal \& Beigh } \\
2017\end{array}$ & $\begin{array}{l}\text { This paper discusses some Computer Ethics' historical milestones and } \\
\text { identifies research questions that have not been addressed sufficiently in the } \\
\text { literature. }\end{array}$ & $\mathrm{CP}$ \\
\hline [23] & $\begin{array}{l}\text { Jurkiewicz } \\
2018\end{array}$ & $\begin{array}{l}\text { This paper outlines some key ethical issues that are emerging as citizens } \\
\text { become aware of the consequences of trading privacy for access. }\end{array}$ & $\mathrm{CP}$ \\
\hline [24] & $\begin{array}{l}\text { Lau \& Yuen } \\
2013\end{array}$ & $\begin{array}{l}\text { This paper explores the influence of gender, religion, and parenting style on } \\
\text { risky online behaviors in a sample of } 825 \text { students in Hong Kong. }\end{array}$ & QN-R \\
\hline
\end{tabular}




\begin{tabular}{|c|c|c|c|}
\hline [25] & Leese 2017 & $\begin{array}{l}\text { This paper highlights the notion of public accountability as a complementary } \\
\text { tool for the establishment of an ethical resonance space for emerging } \\
\text { technologies. }\end{array}$ & $\mathrm{CP}$ \\
\hline [27] & $\begin{array}{l}\text { Mariscal \& } \\
\text { Petropanagos } \\
2016\end{array}$ & $\begin{array}{l}\text { This paper shows why an early identification of technologies as revolutionary } \\
\text { may help the construction of more nuanced and effective ethical frameworks } \\
\text { for public policy. }\end{array}$ & QL-R \\
\hline [29] & $\begin{array}{l}\text { Meek et al. } \\
2016\end{array}$ & $\begin{array}{l}\text { This paper reviews ways to better manage the ethical issues and risks of one } \\
\text { emerging technology: Artificial Intelligence. }\end{array}$ & $\mathrm{CP}$ \\
\hline [31] & $\begin{array}{l}\text { Mladenović et } \\
\text { al. } 2014\end{array}$ & $\begin{array}{l}\text { This paper argues that the anthropocentric design perspective is a necessary } \\
\text { ethical approach to self-driving vehicle technology. }\end{array}$ & QN-R \\
\hline [32] & $\begin{array}{l}\text { Mohamud et al. } \\
2016\end{array}$ & $\begin{array}{l}\text { This paper explores the attitude held by the students of International Islamic } \\
\text { University Malaysia (IIUM) towards information access ethical issues. }\end{array}$ & QN-R \\
\hline [36] & $\begin{array}{l}\text { Nelson \& } \\
\text { Gorichanaz } \\
2019\end{array}$ & $\begin{array}{l}\text { This paper looks at the ethical themes that are operative in the evolving } \\
\text { regulation of drones' ownership and use. }\end{array}$ & QL-R \\
\hline [40] & Saab 2010 & $\begin{array}{l}\text { This paper presents and evaluates an information ethics course, paying } \\
\text { attention to students' receptivity and learning. }\end{array}$ & QL-R \\
\hline [41] & Sandberg 2019 & $\begin{array}{l}\text { This paper reviews the economic consequences of computational speedups and } \\
\text { how these affect risk, ethics and governance. }\end{array}$ & $\mathrm{CP}$ \\
\hline [43] & $\begin{array}{l}\text { Schuurbiers et } \\
\text { al. } 2009\end{array}$ & $\begin{array}{l}\text { This paper presents two advanced courses organised in Oxford and argues that } \\
\text { educational programmes could be a natural extension of ongoing collaborative } \\
\text { research efforts "in the lab". }\end{array}$ & QL-R \\
\hline [44] & $\begin{array}{l}\text { Schuurbiers } \\
2011\end{array}$ & $\begin{array}{l}\text { This paper shows how second-order reflective learning makes the socio-ethical } \\
\text { context of research visible in the laboratory and enables research participants } \\
\text { to more critically reflect on this broader context. }\end{array}$ & QL-R \\
\hline [45] & Singh 2019 & $\begin{array}{l}\text { This paper focuses on ethical challenges or dilemmas for data privacy and } \\
\text { security arising with social media. }\end{array}$ & QN-R \\
\hline [46] & Small 2017 & $\begin{array}{l}\text { The purpose of this paper is to contextualise factors influencing technology } \\
\text { development, to survey emerging digital technologies and to foresight some } \\
\text { potential implications for agricultural enterprises. }\end{array}$ & $\mathrm{CP}$ \\
\hline [48] & $\begin{array}{l}\text { Stahl et al. } \\
2010\end{array}$ & $\begin{array}{l}\text { This paper outlines how the description of emerging ICTs can be used for an } \\
\text { ethical analysis. }\end{array}$ & $\mathrm{CP}$ \\
\hline [49] & $\begin{array}{l}\text { Stahl et al. } \\
2009\end{array}$ & $\begin{array}{l}\text { This paper attempts to provide a framework of technological developments } \\
\text { and ethical issues that are currently expected to arise within the European } \\
\text { Union. }\end{array}$ & $\mathrm{CP}$ \\
\hline [50] & $\begin{array}{l}\text { Stern \& } \\
\text { Grounds } 2011\end{array}$ & $\begin{array}{l}\text { This paper examines how cellular telephones have made it possible for } \\
\text { members of romantically involved couples to keep track of each other. }\end{array}$ & QN-R \\
\hline [51] & $\begin{array}{l}\text { Stylianou \& } \\
\text { Talias } 2015\end{array}$ & $\begin{array}{l}\text { The aim of this paper is to demonstrate that the use of medical lasers has so } \\
\text { greatly influenced our lives that the scientific community must initiate an } \\
\text { earnest discussion of medical laser ethics. }\end{array}$ & $\mathrm{CP}$ \\
\hline [52] & $\begin{array}{l}\text { Tavani \& } \\
\text { Grodzinsky } \\
2019\end{array}$ & $\begin{array}{l}\text { This paper investigates whether Dynamic Ethics and Contextual Integrity, used } \\
\text { together, can provide a more robust scheme for analyzing privacy concerns } \\
\text { within the larger context of big data analytics. }\end{array}$ & $\mathrm{CP}$ \\
\hline [53] & Tavani 2017 & $\begin{array}{l}\text { The purpose of this paper is to show why having a critical reasoning } \\
\text { component is useful to ICT-ethics analysis. }\end{array}$ & $\mathrm{CP}$ \\
\hline [54] & $\begin{array}{l}\text { Timmermans } \\
\text { et al. } 2010\end{array}$ & $\begin{array}{l}\text { This paper sets out to identify ethical issues of cloud computing that arise from } \\
\text { the fundamental nature of this technology. }\end{array}$ & $\mathrm{CP}$ \\
\hline [55] & Tolnaiová 2014 & $\begin{array}{l}\text { This paper concentrates on two agents in "service" for humanising effect of } \\
\text { media: ethics and education. }\end{array}$ & $\mathrm{CP}$ \\
\hline [56] & Tolnaiová 2016 & $\begin{array}{l}\text { This paper focuses on the nature, assessment and regulation of the Internet's } \\
\text { sociocultural impact. }\end{array}$ & $\mathrm{CP}$ \\
\hline [57] & Turculeţ 2014 & $\begin{array}{l}\text { The purpose of this paper is to make a philosophical analysis of three ethical } \\
\text { themes: privacy, anonymity and trust. }\end{array}$ & $\mathrm{CP}$ \\
\hline [58] & $\begin{array}{l}\text { Van Rijmenam } \\
\text { et al. } 2019\end{array}$ & $\begin{array}{l}\text { The aim of this paper is to recognise, theorise and refine governance } \\
\text { mechanisms that ensure responsible AI. }\end{array}$ & QL-R \\
\hline
\end{tabular}


Carignani, A., Gemmo, V., \& Selmi, J. (2019). Paradigm Lost: A Reasoned Review of the Literature on the Relationship between Ethics and Technological Innovation. Advances in Social Sciences Research Journal, 6(12) 168-180.

\begin{tabular}{|l|l|l|c|}
\hline [59] & $\begin{array}{l}\text { Wakunuma \& } \\
\text { Stahl 2014 }\end{array}$ & $\begin{array}{l}\text { The aim of this paper is to identify ethical issues of emerging ICT and to explore } \\
\text { how IS professionals view these issues and how they address them. }\end{array}$ & QL-R \\
\hline [60] & Winter 2014 & $\begin{array}{l}\text { The purpose of this paper is to identify and understand specific changes in } \\
\text { information practices brought about by the IoT that may be perceived as } \\
\text { privacy violations. }\end{array}$ & QN-R \\
\hline [61] & $\begin{array}{l}\text { Wogu et al. } \\
\text { This paper tries to identify the implications for policy formulation of ICTs' } \\
\text { integration into media communication. }\end{array}$ & $\begin{array}{l}\text { This paper proposes a framework for an ethical impact assessment of } \\
\text { information technologies. }\end{array}$ & QL-R \\
\hline [62] & Wright 2011 & $\begin{array}{l}\text { The aim of this paper is to understand how different disciplines involved in } \\
\text { Internet research approach ethical dilemmas and justify their reasoning. }\end{array}$ & QL-R \\
\hline [63] & $\begin{array}{l}\text { Zevenbergen et } \\
\text { al. 2015 }\end{array}$ & \\
\hline
\end{tabular}

$C P=$ Conceptual Paper $/ Q L-R=$ Qualitative research $/ Q N-R=$ Quantitative research 